\title{
СТРУКТУРА ПУБЛИЧНО-ПРАВОВЫХ ПЛАТЕЖЕЙ НЕФТЕГАЗОВЫХ КОМПАНИЙ: РОССИЙСКИЙ И ЗАРУБЕЖНЫЙ ОПЫТ
}

\author{
(C) 2020 Гирфанова Арина Радиковна \\ студентка 4 курса бакалавриата
}

Институт государственной службы и управления Российской академии народного хозяйства и государственной службы при Президенте Российской Федерации, Россия, Москва

E-mail: arina.girfanova@yandex.ru

Реформирование налогообложения нефтегазовой отрасли находится в центре дискурса: говорят как о повышении эффективности «нефтяных денег», так и о чрезмерной налоговой нагрузке на нефтегазовые компании. Ещё один аспект - необходимость развития отрасли, для чего должны привлекаться сами нефтегазовые компании. Изучение российской практики, а также зарубежного опыта позволит определить ряд перспективных направлений развития нефтегазового фискального режима.

Ключевые слова: нефтегазовый фискальный режим, налог на добычу полезных ископаемых, нефтегазовые компании, роялти, налоговые льготы

Нефтегазовый фискальный режим государства представляет собой ряд положений, регулирующих систему отношений, связанных с осуществлением обязательных платежей компаниями нефтегазовой отрасли. Данный режим формируется исходя из ряда параметров, например, таких как право собственности на недра. Налоговое регулирование нефтегазовой отрасли позволяет не только управлять доходами государственного бюджета, но и предлагать стимулы для развития, в том числе за счёт гибкой системы льгот. Кроме того, система лицензирования разведки и добычи оказывает влияние на активность компаний в данной сфере: хотя платежи, связанные с лицензированием, являются неналоговыми, их также необходимо учитывать при проведении анализа фискальной нагрузки на нефтегазовые компании.

Можно выделить несколько базовых подходов к оформлению отношений, связанных с получением прав на добычу нефти или газа:

- концессия - нефтегазовая компания получает эксклюзивное право на разведку и добычу на определенном участке. В данном случае компания платит роялти и налог на прибыль / доход организации (corporate profits / income tax), кроме того, могут взиматься иные платежи, например, ресурсные налоги и экспортные пошлины;

- соглашение о разделе продукции - национальная (государственная) нефтяная компания или правительство заключает договор с нефте- газовой компанией, которая производит разведку и добычу и в качестве вознаграждения получает часть продукта в собственность. Компания может также облагаться другими налогами, например, налог на сверхприбыль;

- сервисный контракт - компания проводит разведку и добычу и получает за это вознаграждение, то есть выполняется функцию подрядчика на участке.

При этом для стран, применяющих концессионную модель, характерно использование двух групп платежей: аккордных и подоходных; в России, Канаде и США применяются обе группы, тогда как в Великобритании и Норвегии компании облагаются только подоходными налогами.

Аккордные платежи могут быть представлены как налоговыми, так и неналоговыми платежами. К разовым неналоговым платежам относятся, например, разовые платежи за пользование недрами при наступлении определённых событий [2], к регулярным неналоговым платежам - регулярные платежи за пользование недрами. Последние представляют собой ренталс и обеспечивают доход государства от использования участка недр независимо от его прибыльности. Таким образом, нефтегазовая компания в начале своей деятельности несёт затраты, связанные не только с подготовкой к добыче сырья, но и с фискальной нагрузкой. Аналогичный подход применяется в США и Канаде: в США бонусная ставка (Bonus Bids) представля- 
ет собой авансовый платеж за право на разведку и добычу, который перекладывает все риски на арендатора - нефтяную компанию. Ставки не равнозначны для различных участков и зависят от того, насколько перспективна разработка территории, а также от ожидаемых будущих цен на нефть и газ и от распределения риска и прибыли между инвестором и государством. Для Великобритании и Норвегии, напротив, не характерно взимание платежей, предваряющее получение прибыли компанией. Таким образом, в России нефтегазовые компании несут фискальную нагрузку ещё на этапе подготовки к добыче задолго до получения прибыли, что может влиять на инвестиционную привлекательность.

Вторая группа платежей - налоги, непосредственно связанные с добычей и реализацией. Более подробно рассмотрим структуру налоговых платежей нефтегазовых компаний в России, США, Канаде, Великобритании и Норвегии.

В соответствии с Налоговым кодексом Российской Федерации нефтегазовые компании являются плательщиками следующих налогов:

- налог на добычу полезны ископаемых (НДПИ);

- налог на прибыль организации;

- налог на дополнительный доход [1].

НДПИ представляет собой основной налог для нефтегазовых компаний. Плательщик НДПИ подлежит налоговому учету по месту нахождения участка недр, то есть в субъекте Российской Федерации, на территории которого он осуществляет добычу полезных ископаемых. Особенность налогообложения нефти, газа и газового конденсата заключается в установлении специфической (твердой) налоговой ставки. НДПИ при добыче нефти рассчитывается как:

Количество добытой нефти (тонны) × Налоговая ставка (919 руб.) × Кц - Дм,

где: Кц - коэффициент, характеризующий динамику мировых цен на нефть, устанавливающийся Федеральной налоговой службой ежемесячно; для расчета налога в мае 2020 года Кц = 4,2792 [3];

Дм - показатель, характеризующий особенность добычи нефти.

При добыче нефти, природного газа и газового конденсата на новых морских месторождениях устанавливается адвалорная ставка.

Министерство финансов Российской Федерации ежегодно публикует информацию об исполнении федерального бюджета; по ито- гам 2019 года нефтегазовые доходы составили 39,25\% всех доходов. Однако в данную категорию входят исключительно НДПИ, НДД и вывозные таможенные пошлины, это обусловлено бюджетным правилом, которое ориентировано на базовый объем нефтегазовых доходов. Вместе с тем в рамках исследования нельзя оставить без внимания налог на прибыль организации, платежи по которому непосредственно связаны с добычей и, главное, рентабельностью. Налог на прибыль, в отличие от НДПИ, учитывает финансовый результат и зависит от многих факторов, в связи с чем его сложнее прогнозировать, в то время как прогноз НДПИ основывается на планах по объему добычи.

Налог на дополнительный доход был введен Федеральным законом в 2018 году; он взимается с дополнительного дохода, получаемого на определенных участках недр, находящихся в границах новых месторождений (greenfields) Восточной и Западной Сибири и действующих месторождений, а также месторождений российского сектора Каспийского моря. Налоговая база для НДД определяется как расчётная выручка от реализации уменьшенная на величину фактических и расчётных расходов. Новый налог служит стимулом для нефтегазовых компаний, которые могут направлять инвестиции для запуска и развития новых проектов без необходимости выплачивать налоги до получения реальных финансовых результатов.

Система налогов, которым облагаются нефтегазовые компании, предусматривает ряд вычетов, в частности специальные вычеты предоставляются компаниям ХMAO, Республики Крым, компаниям при добыче газового конденсата и нефти с определенными характеристиками. Несмотря на обобщённый вид, вычеты имеют достаточно адресный характер, в связи с чем экспертное сообщество часто высказывается о возможности лоббизма в данной сфере со стороны наиболее влиятельных компаний.

В Соединенных Штатах Америки отраслевые выплаты нефтегазовых компаний состоят из комбинации корпоративного подоходного налога (corporate income tax), налога на добычу полезных ископаемых (severance tax) [6] и роялти. Роялти составляют от $12,5 \%$ до 30\% и зависят от соглашения между компанией и собственником, корпоративный подоходный налог составляет 21\% [8], НДПИ устанавливается штатом и может носить как адвалорный, так и твёрдый 
характер. Кроме того, отдельными штатами может вводиться налог с доходов компании и налог на франшизу, основываемый на стоимости активов или основного капитала. Налогоплательщик может претендовать на налоговые льготы на основании затрат на НИОКР за 3 предыдущих налоговых года. Кроме того, предусмотрены налоговые вычеты по меньшему из значений: 6\% от расходов на добычу или 50\% от фонда оплаты труда. В целом скелет системы налогообложения нефтегазовых компаний США близок к системе в России, разница заключается в том, что в дополнение к федеральным налогам и налогам штата и муниципалитета нефтегазовые компании выплачивают роялти в пользу собственника недр.

Фискальный режим в нефтегазовой отрасли Канады состоит из роялти и подоходного налога [5]. Подоходный налог представлен федеральным налогом со ставкой $15 \%$ и налогом провинции - от $11,5 \%$ до $16 \%$, в зависимости от территории. Королевские роялти применяются для государственных земель и доходят до $45 \%$, кроме того права на полезные ископаемые могут принадлежать провинциям или территориальным правительствам, а также коренным народам. Роялти, выплачиваемые частным собственникам, как правило связаны с выработкой и варьируются в зависимости от соглашения. Роялти вычитаются при определении дохода для налогообложения. В качестве налоговой льготы компании могут запросить инвестиционный налоговый кредит (Investment Tax Credit), снижающий налогооблагаемую базу подоходного налога на $15 \%$ при условии, что компания проводила инвестиции в исследования и модернизацию на протяжении налогового периода или создала новые рабочие места для обучающихся. Система платежей нефтегазовых компаний имеет достаточно сложную структуру в связи с тем, что собственниками недр могут являться различные группы лиц, вместе с тем, правительство разработало достаточно эффективный способ поддержки компаний и привлечения инвестиций в исследования и разработки, который позволяет получить льготу в том случае, если компания действительно направляет ресурсы для развития отрасли.

Особенность Великобритании состоит в том, что нефтегазовые компании не выплачивают роялти; они облагаются налогом на прибыль [7] и налогом на доходы от нефти. Таким образом в Великобритании облагается не объем добычи, а финансовый результат компании. Ещё одна особенность - использование выделения доходов (ring-fencing) от разведки и добычи и доходов от переработки; убытки, понесённые в невыделенной категории, не могут быть компенсированы прибылью выделенной категории, однако, это работает в обратном направлении. Ставка налога на доходы от нефти с 2016 года составляет 0\%. В Норвегии аналогично Великобритании не применяются роялти, компании выплачивают налог на прибыль по ставке $22 \%$ и ресурсную ренту $56 \%$ с чистой операционной прибыли от добывающей деятельности [4]. В Норвегии применяется принцип, который схож с выделением доходов в Великобритании, однако в данном случае выделение происходит не на основании вида деятельности, а по территориальному принципу разделяются доходы и расходы от деятельности компании на суше и в море. Великобритания и Норвегия применяет налогообложение финансового результата, а не объёмов выработки, что позволяет компаниям выделять ресурсы для проведения инвестиционной политики в сфере развития технологий добычи нефти и газа.

На сегодняшний день правительства заинтересованы не только в получении дохода в бюджет, но и в развитии технологий нефтегазодобывающей отрасли. В связи с чем используются различные подходы, главной целью которых является привлечение нефтегазовых компаний к инвестированию в НИОКР в данной сфере. В качестве одной из целей введения налога на дополнительный доход декларировалось именно повышение интереса компаний к направлению части средств на исследования и развитие: подразумевалось, что компании будут активнее инвестировать в НИОКР, так как они смогут «перенести» налоги на момент получения прибыли. Вместе с тем, НДД вызывает беспокойство в части возникновения рисков завышения уровня расходов компании с целью снижения налогооблагаемой базы. В то же время, ряд нефтедобывающих стран отказался от аккордных налогов в пользу налогообложения финансовых результатов, подобный подход снижает нагрузку и, как следствие, быстрое истощение месторождений с относительно «лёгкой» добычей. Наиболее эффективным способом привлечения нефтегазовых компаний в развитию отрасли видится подход, который был выбран правительством Канады, а именно получение налоговых льгот по результатам реального участия в НИОКР. 


\section{Библиографический список}

1. Налоговый кодекс Российской Федерации. Часть вторая от 05.08.2000 № 117-ФЗ // Собрание законодательства Российской Федерации. - 2000. - № 32, ст. 3340.

2. О недрах: закон Российской Федерации от 21.02.1992 № 2395-I // Ведомости Съезда народных депутатов Российской Федерации и Верховного Совета Российской Федерации.- 1992.- № 16, ст. 834.

3. Данные, необходимые для исчисления НДПИ в отношении нефти, НДД и акциза на нефтяное сырье, за май 2020 года: письмо ФНС России от 11.06.2020 № СД-4-3/9727.

4. The Petroleum Taxation Act: act 13.06.1975 № 35 .

5. Income Tax Act.- R.S.C. - 1985.- c.1.

6. The Internal Revenue Code.-26 U.S.C. -1986.

7. To restate, with minor changes, certain enactments relating to corporation tax and certain enactments relating to company distributions; and for connected purposes: an act 03.03.2010.-2010.- c. 4.

8. To provide for reconciliation pursuant to titles II and V of the concurrent resolution on the budget for fiscal year 2018: an act 10.02.2017 Public Law 115-97. 